\title{
MASS BALANCE STUDIES ON THE HINTEREISFERNER, ÖTZTAL ALPS, 1952-1961
}

\author{
By H. Hoinkes and R. Rudolph \\ (Universität Innsbruck, Institut für Meteorologie und Geophysik)
}

\begin{abstract}
Investigations of the mass balance of the Hintereisferner are dealt with for the period $1952-6 \mathrm{I}$. Ablation of ice was measured with stakes, ten of which per square kilometre were considered as a sufficient number. The area of ice ablation terminates in the "zero-line of ice ablation". The net accumulation was studied in pits, and by mapping of enduring accumulation patterns. In order to avoid errors it is proposed that the term "firn line" be replaced by the term "old snow line". This would more clearly emphasize that only the net accumulation of old snow from the current budget year is a gain of mass for the glacier. The term "firn", in accordance with Flint's [1957] definition should be used only for snow more than one year old. Between the old snow line and the zero-line of ice ablation in some years an appreciable firn ablation takes place. The mass balance reveals a large variation between $+0.77 \times 10^{6} \mathrm{~m} .3$ of water in the most favourable budget year $1954-55$, and $-9.83 \times 10^{6} \mathrm{~m} .3$ of water in the most unfavourable budget year $1957-58$. The average annual mass balance was $-3.60 \times 10^{6} \mathrm{~m} .3$ of water, with an estimated maximum possible error of about $\pm 0.54 \times 10^{6} \mathrm{~m} .3$ of water.
\end{abstract}

RÉsumé. On présente, pour la période comprise entre 1952 et 1961, les études du bilan de masse du Hintereisferner. L'ablation de la glace a été mesurée avec des balises, pour lesquelles le nombre de 10 par $\mathrm{km}^{2}$ a été jugé suffisant. La zone d'ablation de la glace s'arrête à la "ligne zéro d'ablation de la glace". L'accumulation nette a été étudiée dans des puits, et à l'aide de cartes de durées des caractères de l'accumulation. Afin d'éviter les erreurs on se propose de remplacer le terme "ligne de névé" par le terme "ligne de vieille neige". Ceci mettrait en évidence plus clairement que seule l'accumulation nette de vieille neige, provenant du budget annuel courant, est un gain de masse pour le glacier. Le terme "névé", en accord avec la définition de Flint [1957], devrait être utilisé uniquement pour la neige âgée de plus d'un an. Pour certaines années il y a une ablation de névé appréciable entre la "ligne de vieille neige" et la "ligne zéro d'ablation de la glace". Le bilan de masse présente une forte variation entre une valeur en eau de $+0,77 \times 1_{10}^{6} \mathrm{~m}^{3}$ pour le budget annuel le plus favorable ( $1945-55)$, et une valeur en eau de $-9,83 \times 10^{6} \mathrm{~m}^{3}$ pour le budget annuel le plus défavorable (1957-58). Le bilan de masse annuel moyen avait une valeur en eau de $-3,60 \times 10^{6} \mathrm{~m}^{3}$, avec une erreur maximum possible estimée à environ $\pm 0,54 \times 10^{6} \mathrm{~m}^{3}$ (valeur en eau).

Zusammenfassung. Es wird über Untersuchungen des Massenhaushaltes am Hintereisferner in den Jahren 1952 bis 1961 berichtet. Die Ablation von Eis wurde mit Pegeln gemessen, von denen etwa $10 \mathrm{pro}^{2} \mathrm{~km}^{2}$ als ausreichend angesehen wurden. Das Gebiet mit Eisablation wird nach oben begrenzt durch die "Null-Linie der Eisablation". Die Nettoakkumulation wurde in Schneeschächten studiert, sowie durch die Kartierung von stationären "Rücklagen-Mustern". Um Irrtümer zu vermeiden, wird vorgeschlagen, den Ausdruck "Firnlinie" durch "Altschneelinie" zu ersetzen. Dadurch liesse sich klarer zum Ausdruck bringen, dass nur die Nettoakkumulation von Altschnee aus dem laufenden Haushaltsjahr einen Massengewinn für den Gletscher bedeutet. Der Ausdruck "Firn" sollte, in Übereinstimmung mit Flint's [1957] Definition, nur für Schnee verwendet werden, der mehr als ein Jahr alt ist. Zwischen der Altschneelinie und der Null-Linie der Eisablation kommt es in einigen Jahren zu erheblicher Firnablation. Der Massenhaushalt schwankte zwischen $+0,77 \times 10^{6} \mathrm{~m}^{3}$ Wasser im günstigsten Haushaltsjahr $1954-55$, und $-9,83 \times 10^{6} \mathrm{~m}^{3}$ Wasser im ungünstigsten Haushaltsjahr $1957-58$. Der mittlere jährliche Massenhaushalt war $-3,60 \times 10^{6} \mathrm{~m}^{3}$ Wasser, der maximal mögliche Fehler wird auf $\pm 0,54 \times 10^{6} \mathrm{~m}^{3}$ Wasser geschätzt.

\section{INTRODUCTION}

Investigations of the mass balance of the Hintereisferner began in the autumn of $195^{2}$, when Schimpp (1958, I 960) placed 54 wooden stakes in eleven profiles across the glacier and surveyed them several times between February 1953 and September 1954. In the spring of I 954 an additional 40 stakes were placed by Rudolph (in press) and ablation and accumulation measured for one year, as well as the discharge from the glacier. Since the results from three precipitation gauges within the drainage area were available (Hoinkes, I954), it became possible to apply the mass balance equation

$$
\mathcal{N}-A-V=R-B
$$

for the hydrological year I October 1953 to 30 September 1954. ( $\mathcal{N}=$ total precipitation, $A=$ discharge, $V=$ total evaporation, $R=$ net accumulation, $B=$ net ablation.)

Beginning from the autumn of 1954 the network of stakes was kept under continuous observation on a somewhat reduced scale by Hoinkes (1959). Comprehensive studies of the winter snow cover at the end of the hydrological winter half-year began in the spring of I955, 
which were chiefly used to determine the total precipitation (Hoinkes and Lang, in press [a]) for the drainage area. This could be done to the best advantage during the hydrological years 1957-58 and 1958-59, when a recording stream gauge was operating at the same spot where the discharge had been measured in 1954. In the summer of 1956 an additional precipitation gauge was set up; beginning from the autumn of 1959 a fifth gauge became available.

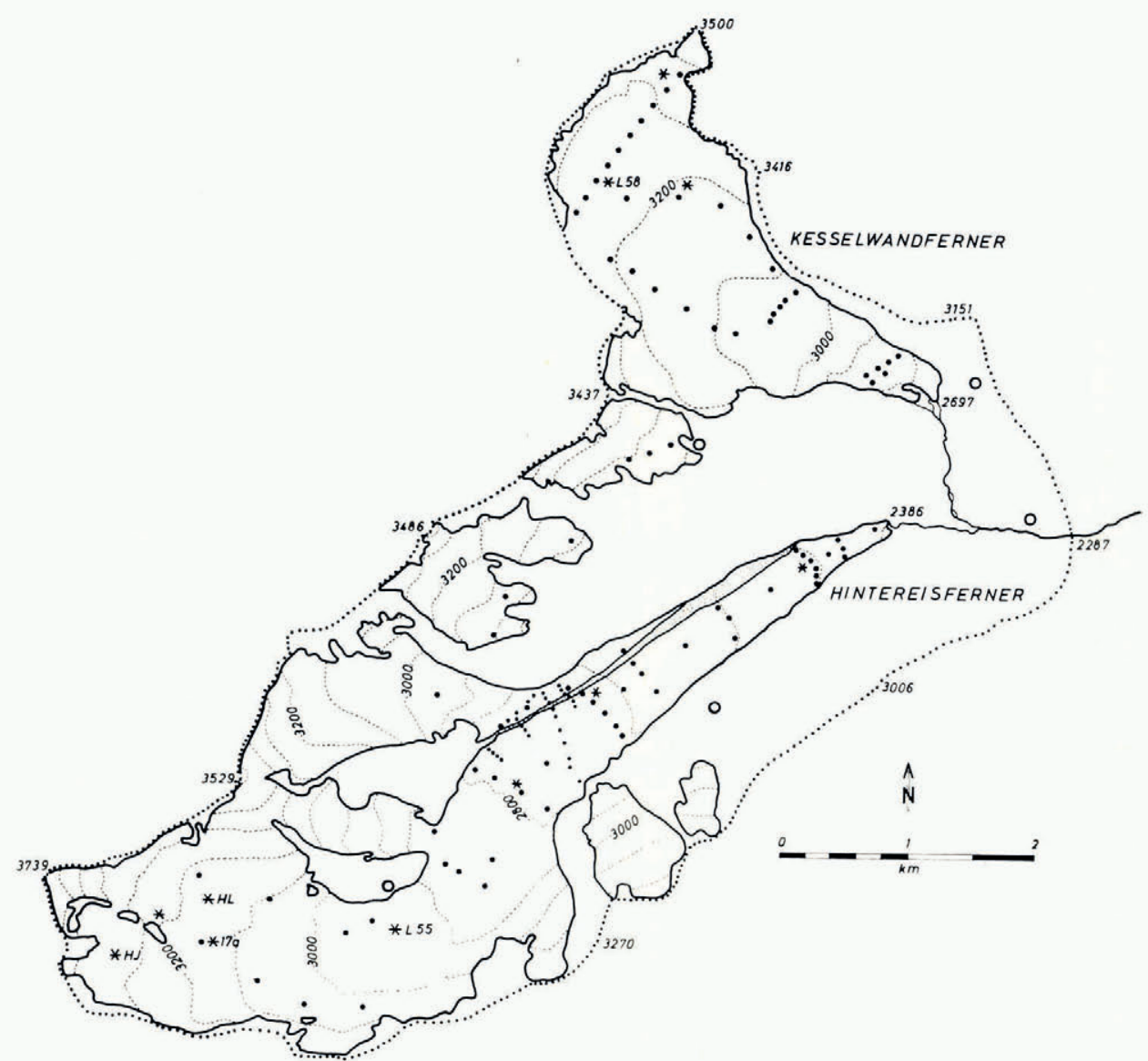

Fig. I. The drainage area $\left(26.6 \mathrm{~km} .^{2}\right)$ of the Hintereisferner and the Kesselwandferner, Ötztal Alps. Heights in metres a.s.l., interval of contour lines $100 \mathrm{~m}$. Positions of ablation stakes $(\bullet)$, snow pits $(\boldsymbol{*})$ and rain gauges $(\mathbf{O})$ are shown for 1959

The drainage area of the stream gauge is shown in Figure I. It comprises $26 \cdot 62 \mathrm{~km} .^{2}$, $5^{8}$ per cent of which was ice-covered in 1959 , i.e. Hintereisferner $9 \cdot 97 \mathrm{~km} .^{2}$, Kesselwandferner $4.06 \mathrm{~km} .{ }^{2}$, slope glaciers $\mathrm{I} \cdot 4^{2} \mathrm{~km} .^{2}{ }^{*}$ The average height of the drainage area is $2,98 \mathrm{I} \mathrm{m}$., the stream gauge as the lowest point is situated at $2,287 \mathrm{~m}$., the highest peak, Weisskugel, reaches $3,739 \mathrm{~m}$. For the periods of the I.G.Y. I957-58 and the I.G.C. I 959 the number of ablation and accumulation stakes was raised to a total of I I 7,35 of which were placed on the Kesselwandferner. The determination of the mass balance of the glaciers within the drainage area for the hydrological years $1957^{-58}$ and $195^{8-59}$ was dealt with

* According to photogrammetric surveys, carried out in 1953 and I959 by the Institut für Photogrammetrie, Topographie und Allgemeine Kartographie, Technische Hochschule München, which were placed at our disposal by courtesy of Prof. Dr. R. Finsterwalder. 
in detail in a report by Hoinkes and Lang (in press [b]). Again two methods could be used, since the constituent parts of the mass balance equation were measured directly. Only the total evaporation remained to be estimated. The comparison of the best estimates available with the value calculated from $V=\mathcal{N}-A-(R-B)$ served as a check for the reliability of the measured quantities $\mathcal{N}, A$ and $(R-B)$. It is, therefore, highly advantageous to measure precipitation and discharge at least for some years in addition to accumulation and ablation. Since the autumn of r959 the observations have continued, again on a reduced scale, to the present date.

For the period 1957-59 the most complete data are available, and these are therefore the most suitable data from which to start to interpret the observations collected in previous and in following years. These observations were, as in most cases of mass balance studies, restricted to net accumulation and net ablation. The following remarks, therefore, will deal mainly with the interpretation of such observations, according to the experience gained on the Hintereisferner. A report about measurements of run-off from the glaciers is in preparation.

\section{Net Ablation of Ice}

Ablation stakes on the Hintereisferner were placed, as can be seen from Figure I, in several cross profiles, connected through one longitudinal profile. Until 1957 square stakes $(3 \times 3 \mathrm{~cm}$., length $\mathrm{I} \mathrm{m}$.) were used, most of which were then replaced by white round stakes of hard wood (diameter $2 \mathrm{~cm}$., length $2 \mathrm{~m}$.). The two types of stake could be joined together by means of metal bolts or sockets respectively. As long as the boreholes were deeper than about one metre, good ablation values could be obtained. This was checked by measuring the depths of adjacent bore holes not containing stakes over periods of several days. With a sufficient number of properly set ablation stakes it is possible to measure total net ablation of ice for a whole ablation season with an accuracy of better than \pm 5 per cent. A number of about ten ablation stakes per square kilometre is considered as "sufficient". This was proved

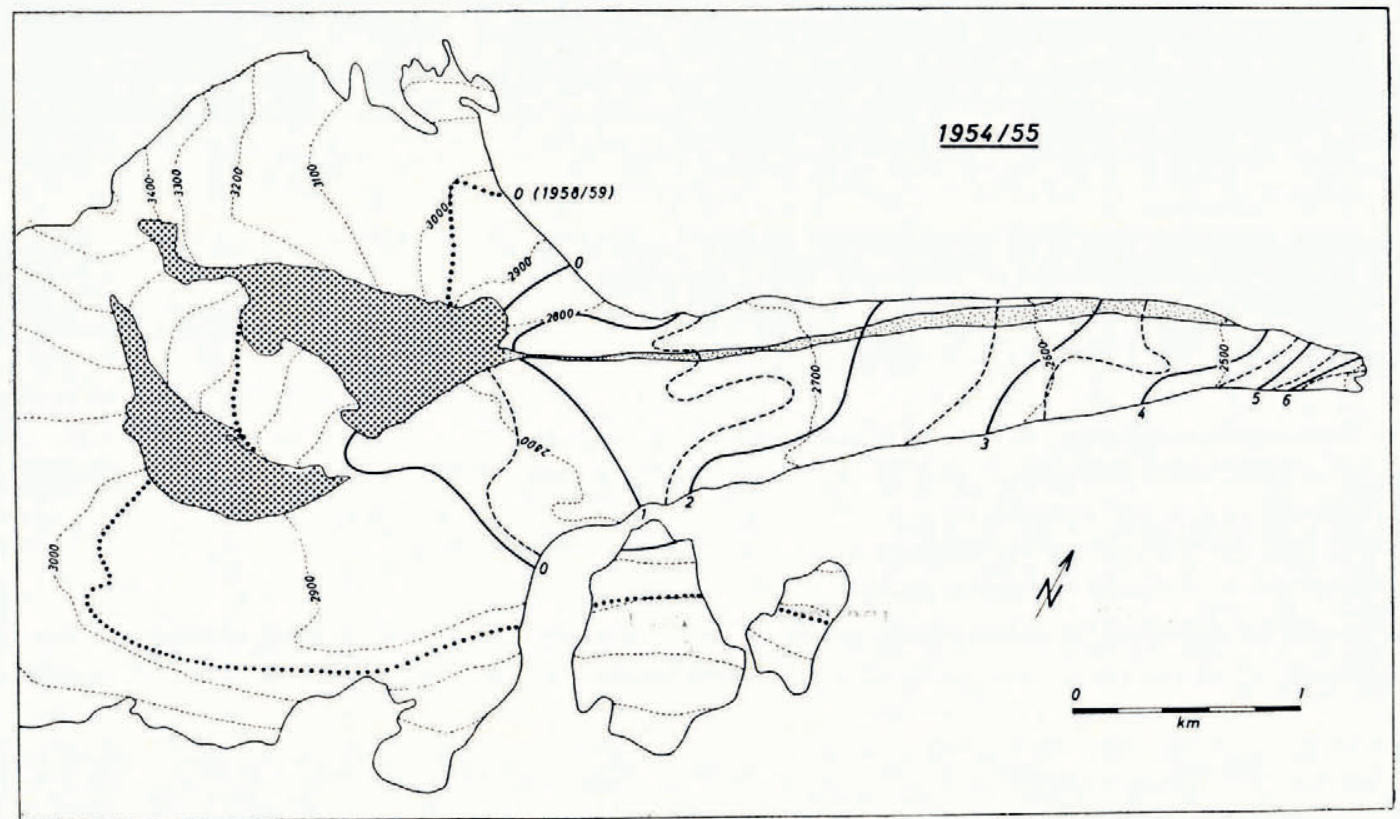

Fig. 2. Net ablation in metres of ice, Hintereisferner, budget year 1954-55. During the period 1952-6I the zero-line of ice ablation was in its lowest position in 1954-55, and in its highest in 1958-59 (indicated by heavy dotted line) 


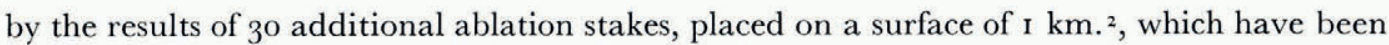
used since 1957 by W. Ambach for studies of surface movement.

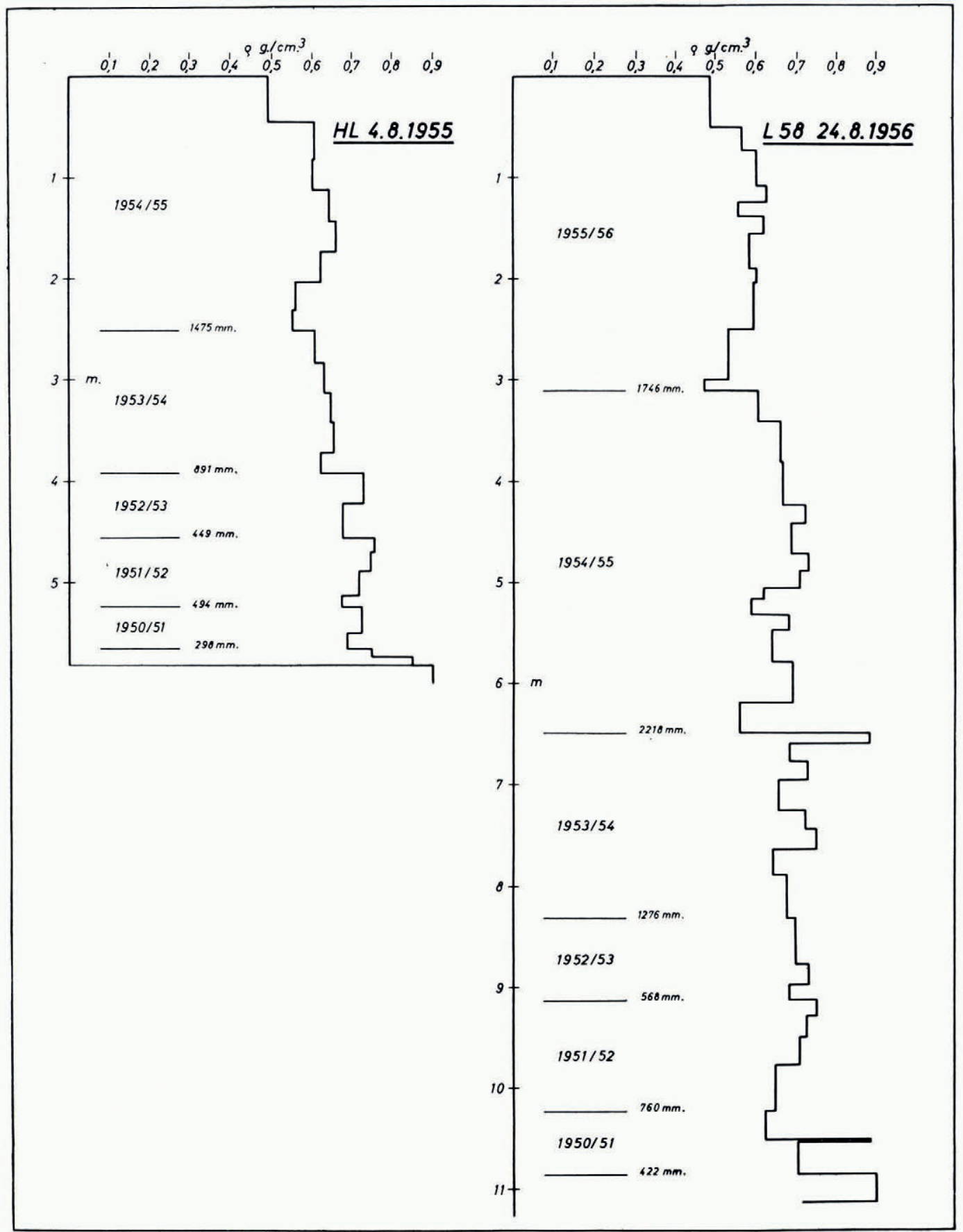

Fig. 3. Net annual accumulation for deep pit $H L$, at $3,170 \mathrm{~m}$. on the Hintereisferner, and deep pit $L 5^{8}$, at $3,240 \mathrm{~m}$. on the Kesselwandferner. Depth in metres, water equivalent in millimetres 
The values of net ablation of ice for each ablation season were entered on maps at a scale of $\mathrm{I}: \mathrm{IO}, \mathrm{OOO}$, and lines of equal ablation were drawn at intervals of $50 \mathrm{~cm}$. of ice. Figure 2 shows the analysis of net ablation for the 1954-55 ablation season, which, according to Table I, had the smallest loss of ice in the period $195^{2}$ to I 96 I. Areas between single lines were measured by planimeter, multiplied by the respective average ablation value and added up, to give the total net ablation in cubic metres of ice. Detailed calculations and maps were published by Rudolph (in press) for the 1953-54 ablation season, and by Hoinkes and Lang (in press [b]) for the $195^{8}$ and 1959 ablation seasons. The zero-line of ice ablation separates the area with unequivocal net mass loss from the area where there might be either gain or loss of mass. Above the zero-line of ice ablation begins the usually narrow zone of superimposed ice, after which the glacier remains covered with either old snow or firn until the end of the ablation season. The superimposed ice, by thorough inspection, can be distinguished from older glacial ice because of its peculiar structure (Hoinkes, I 956). Detailed studies of the formation of superimposed ice were carried out on the Hintereisferner by Ambach (I96r). The zero-line of ice ablation can be, but is not necessarily, identical with the firn line or zero-line with respect to the mass budget. Nevertheless, the zero-line of ice ablation is considered as a fundamental line with clear conditions, i.e. net mass loss below it, which can unmistakably be identified by means of stake observations. It changes its position on the glacier from year to year, thus enlarging or reducing the area with comparably low albedo. In Figure 2 the lowest position of the zero-line of ice ablation is shown at the end of the budget year 1954-55, together with its highest position at the end of the budget year $195^{8-59}$ (dotted line). The corresponding areas with ice ablation were $2.5^{8} \mathrm{~km} .^{2}$ (1955) and $4.3^{0} \mathrm{~km}^{2}{ }^{2}$ (1959), as can be seen from Table I. Within the nine years October $195^{2}$ to September I96I the Hintereisferner lost a total of $64.55 \times \mathrm{IO}^{6} \mathrm{~m} \cdot .^{3}$ of ice or $5^{8 \cdot 10} \times \mathrm{IO}^{6} \mathrm{~m} .3^{3}$ of water. The average annual ice loss amounts to $7 \cdot 17 \times 10^{6} \mathrm{~m} .{ }^{3}$ $\left(6.45 \times 10^{6} \mathrm{~m} .{ }^{3}\right.$ of water $)$ on an average area of $3.35 \mathrm{~km} .{ }^{2}$, viz. an average net ablation of $214 \mathrm{~cm}$. of ice or $193 \mathrm{~cm}$. of water per year.

\section{Net Aggumulation}

Investigations of net accumulation in deep pits began on the Hintereisferner in the summer of 1955, and were extended to the Kesselwandferner in the summer of 1956. The water equivalent of the snow was measured with a snow sampler (area $5^{0} \mathrm{~cm}^{2}$, length $50 \mathrm{~cm}$.), which was weighed with a steelyard ( $5 \mathrm{~g}$. corresponding to $\mathrm{I} \mathrm{mm}$. of water). In a short

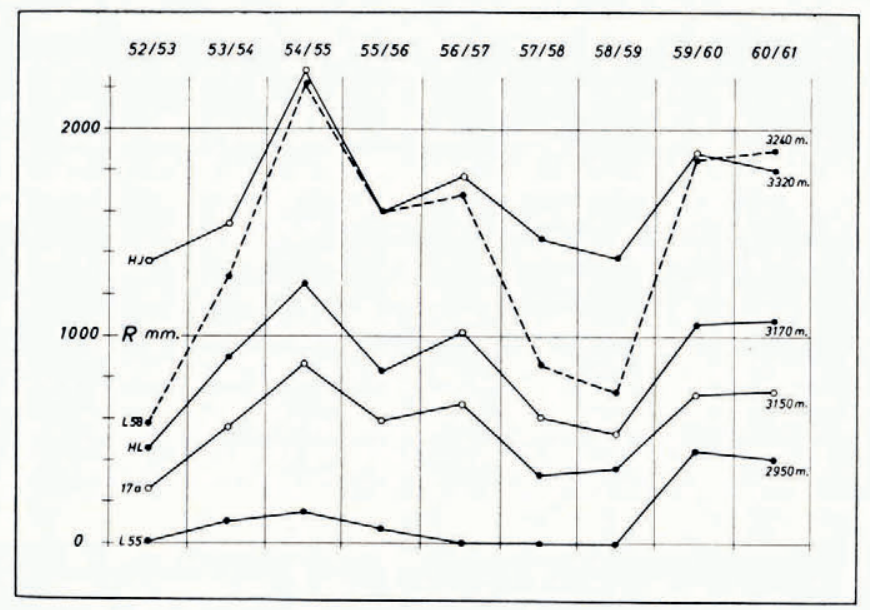

Fig. 4. Net annual accumulation for selected sites on the Hintereisferner and for point $L_{5} 8$ on the Kesselwandferner for the period 1952-53 to 1960-61. Millimetres of water 


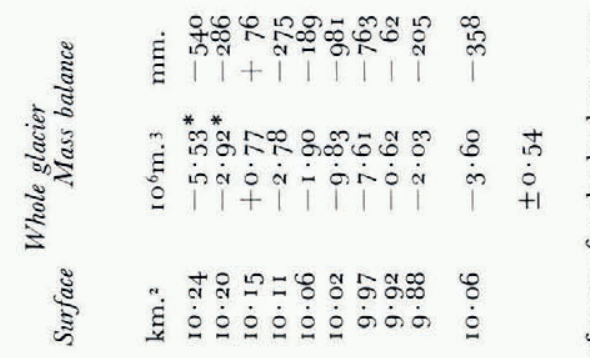

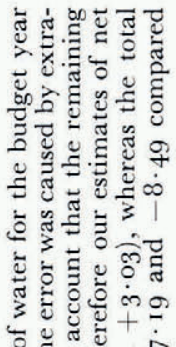

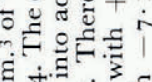

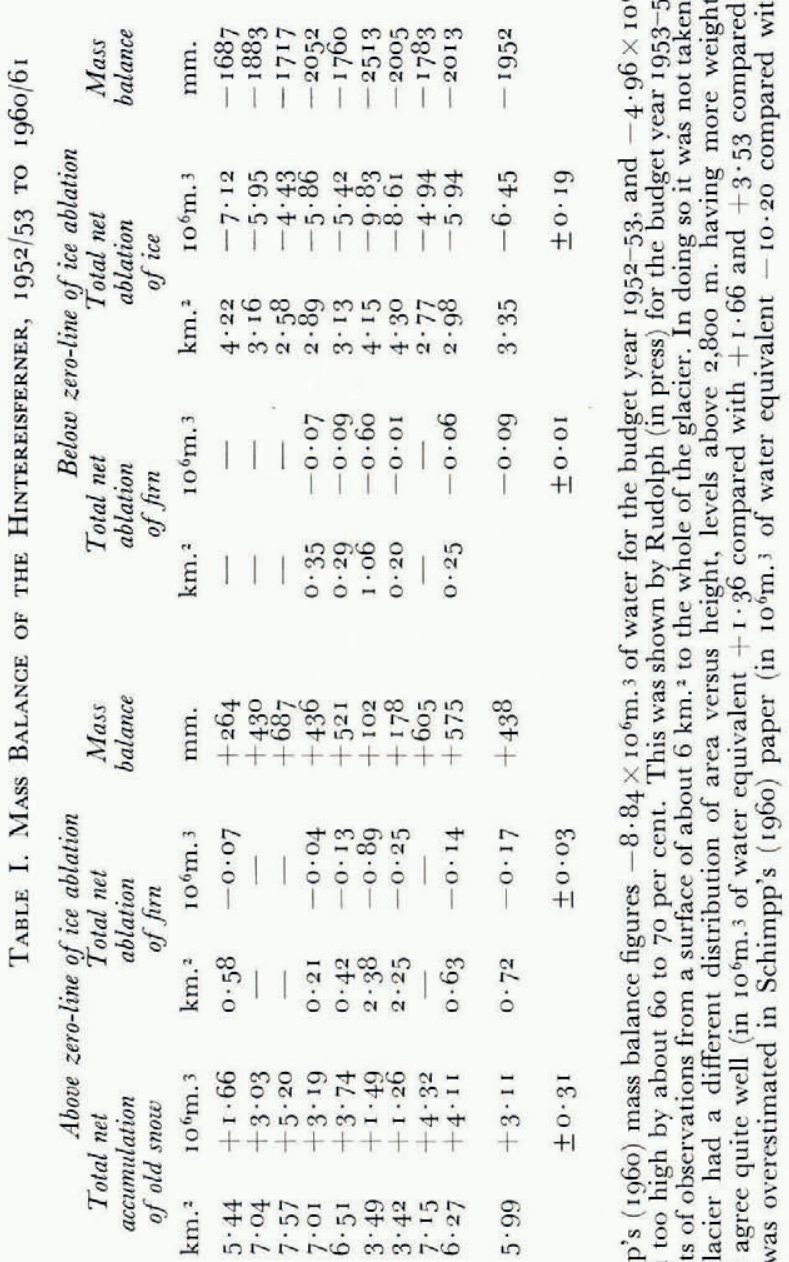

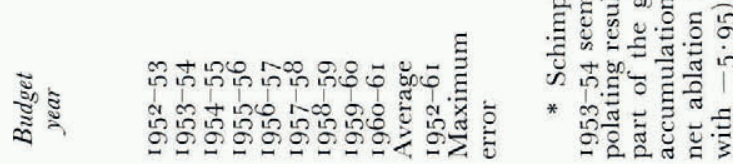


preliminary report about this work (Hoinkes, I957) it was stated that the typical distribution of density with depth, as found in the winter snow cover, showing a minimum at the bottom and a maximum somewhere in the middle of the layer, is preserved for many years. For this reason it can be used as a means for the detection of annual boundaries, together with changes in grain size and colour. The revised results of both deep pits are given in Figure 3 back to the budget year 1950-51, and a definite relation between both accumulation areas can be deduced. This valuable result was confirmed during the budget years $1957-58$ and $195^{8-59}$, when five pits on the Hintereisferner and six pits on the Kesselwandferner were dug, some of them down to the 1956 horizon (Hoinkes and Lang, in press [b]). Some additional values could be obtained from accumulation stakes, the readings of which were converted into water equivalent, using densities from nearby pits. Net accumulation values for a few selected points on the Hintereisferner and for the point L $5^{8}$ on the Kesselwandferner, covering the whole period I952-53 to $1960-6 \mathrm{I}$, are shown in Figure 4. There is a well pronounced increase in net accumulation between 3, I $00 \mathrm{~m}$. and $3,300 \mathrm{~m}$. a.s.l. and only a slight increase within the highest firn basins, which extend to $3,400 \mathrm{~m}$. The relation net accumulation versus height was analyzed for each budget year; Figure 5 shows the limits for high (1954-55) and low (1957-58) net accumulation for the period under consideration.

In order to get the total net accumulation for a budget year, it was tried at first to multiply the average net accumulation in steps of 100 metres by the corresponding glacierized area. By adding up for the two budget years shown in Figure 5, total net accumulations of about $7 \times 10^{6} \mathrm{~m} \cdot{ }^{3}$ of water $(1954-55)$ and about $3 \times 10^{6} \mathrm{~m} \cdot{ }^{3}$ of water $\left(1957^{-58}\right)$ are obtained; the latter figure is obviously too high, because it does not fit the mass balance equation. The true, or at least better, values of net accumulation, according to Table I, are only about 75 and $5^{\circ}$ per cent, respectively, of the first estimates. This simple and frequently used method can be expected to give satisfactory results only if the measured net accumulation is truly representative of its height zone. This demand is not easy to realize, at least not on crevassed alpine glaciers, where pits are normally dug in basins rather than on ridges for safety reasons.

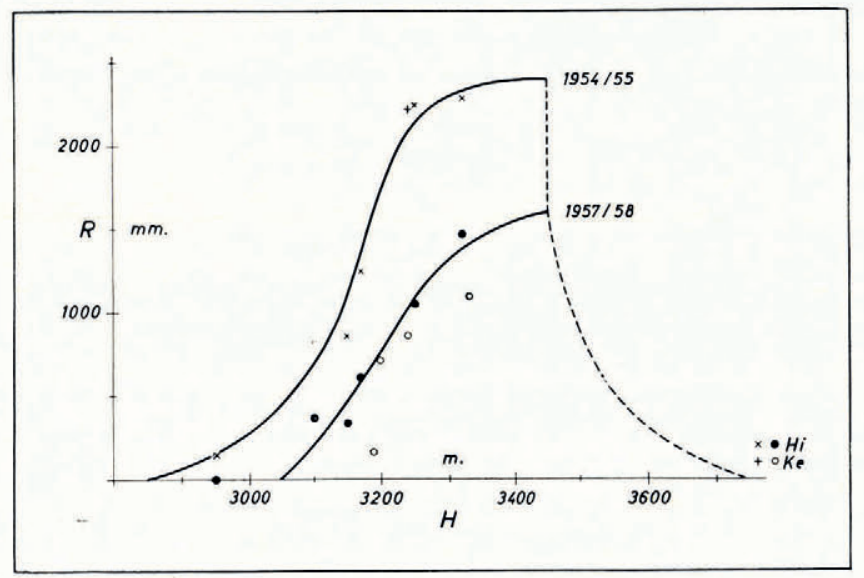

Fig. 5. The relation net accumulation (millimetres of water) versus height (metres) on the Hintereisferner and Kesselwandferner for a budget year with high $\left(1954^{-55)}\right.$ and low $\left(1957^{-58)}\right.$ net accumulation

As can be seen from Figures 6 and 7, no closed cover of old snow remained in the area of nourishment of the Hintereisferner and the Kesselwandferner in the autumns of 1958 and 1959 . Areas having net accumulation of old snow from the current budget year are clearly distinguishable from areas where several layers of older firn snow are exposed to ablation. The border-line between old snow and firn snow should be called the old snow line; it is another 
fundamental line within which clear conditions, i.e. net mass gain, prevail. The "old snow line" or a line very close to it within which the water equivalent of the superimposed ice exceeds the ablation of firn snow, separates the area with positive economy from the area with negative economy. This is the exact meaning of the terms "firn line" or "firn limit". The term "firn line" nevertheless seems to be somewhat unfortunate, because under conditions of retreating "firn line" (as in Figures 6 and 7) the "firn line" runs across the firn snow. It is open to question whether or not all observers distinguish between "old snow" from the current budget year and "firn snow" from budget years before, and therefore some might be tempted to identify as the firn line the beginning of the firn cover (i.e. the zero-line of ice ablation). The adoption of the term "old snow line", which would be helpful in avoiding

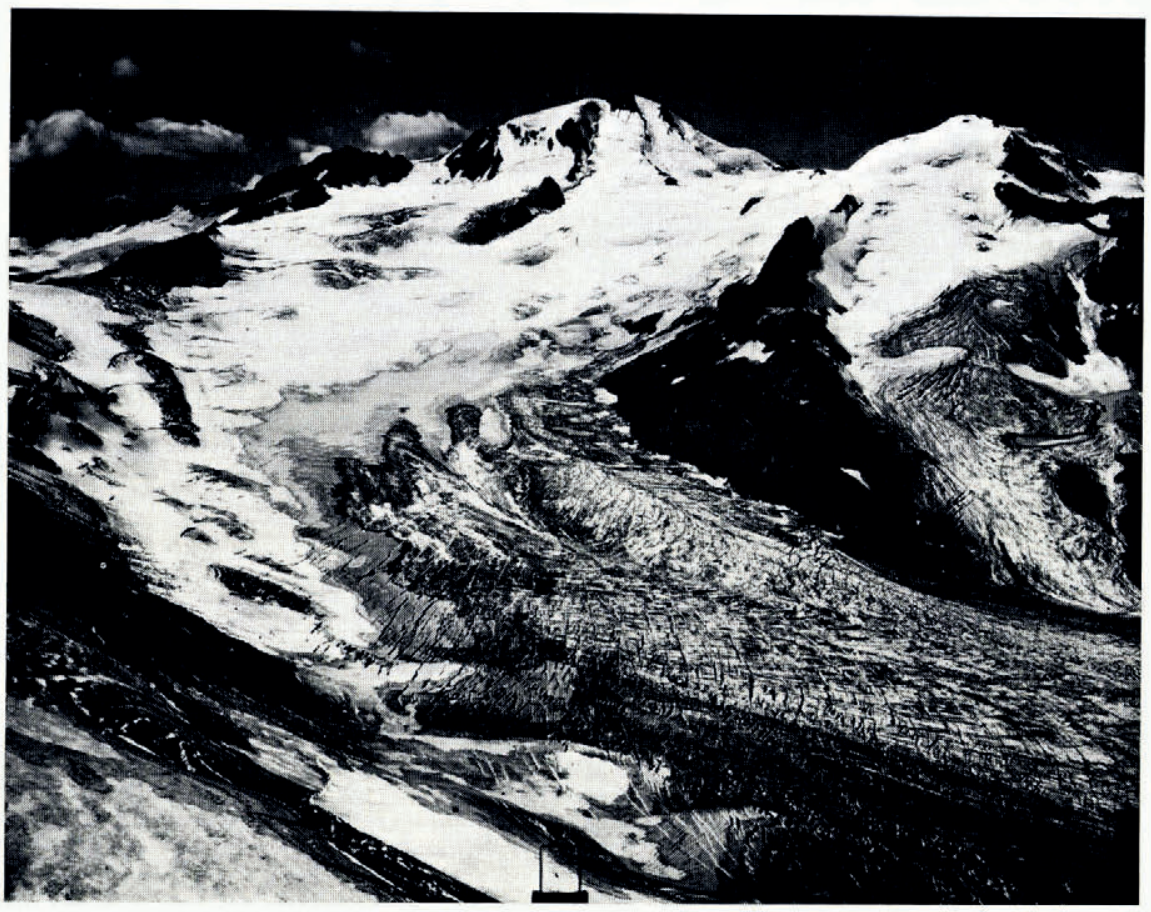

Fig. 6. The upper part of the Hintereisferner with the peaks Weisskugel $(3,739 \mathrm{~m}$.) and Langtaufererspitze $(3,529 \mathrm{~m}$., to the right). The transition zone: glacier ice-superimposed ice-firn snow from five years-old snow from the current budget year shows clearly. Photograph taken 6 September 1958, by Institut für Photogrammetrie, Topographie und Allgemeine Kartographie, Technische Hochschule München. Courtesy Prof. R. Finsterwalder

errors, as it would presuppose only the recollection of the meaning of the German word Firn (= of last year). Consequently Flint (1957) writes: "The process of growth and change is one of recrystallization, and the result is compact granular snow. Such snow, when more than one year old, is known as firn or névé". The otherwise excellent definitions of the terms "old snow" and "firn", given by Armstrong and Roberts (1958), should require a short addition with respect to time. A lower density limit for firn "greater than 0.55 " (Sharp, 1960) does not seem very fortunate, because on polar glaciers the density of firn is frequently below $0 \cdot 55 \mathrm{~g} . / \mathrm{cm} .^{3}$.

Comparison of photographs taken in late summer of different years, reveals that the accumulation patterns are not distributed at random in single years, but remain rather stationary, changing more in size than in shape. This fact was clearly pointed out by Friedel 


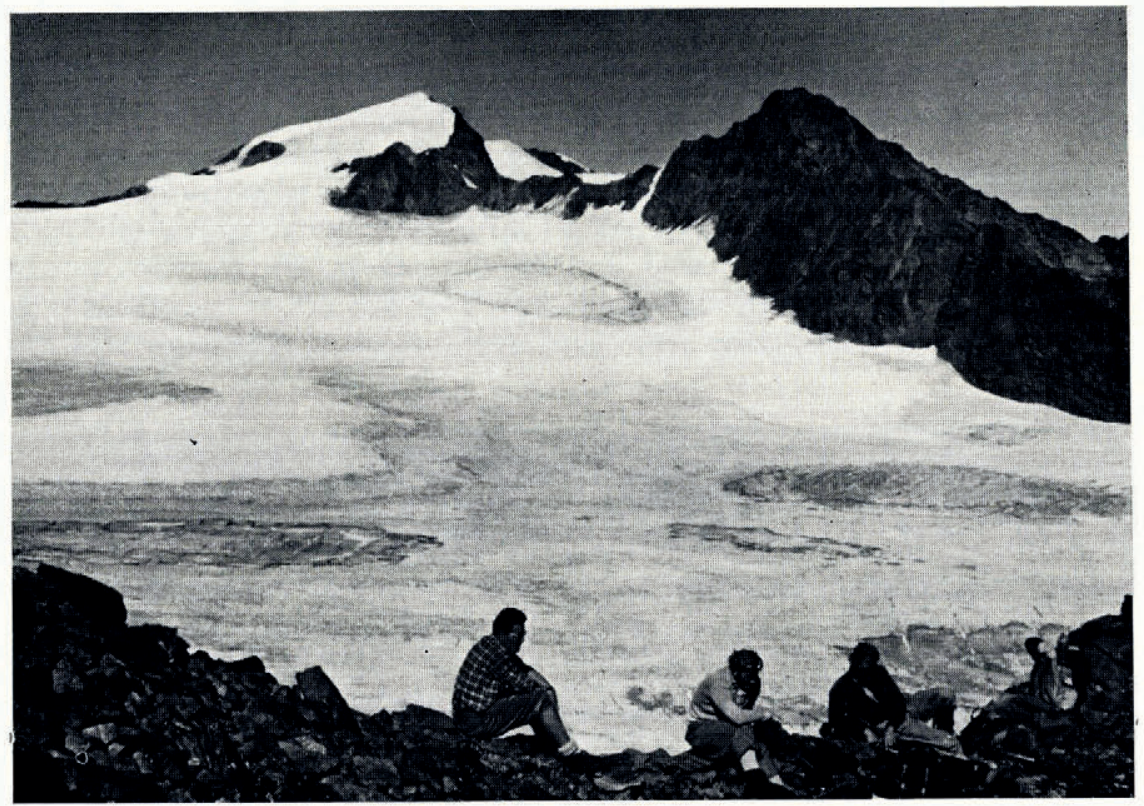

Fig. 7. The upper part of the Kesselwandferner with the peaks Fluchtkogel (3,500 m., left) and Kesselwandspitze (3,4I6 m., right). Typical accumulation patterns. Firn snow from five years exposed to ablation. White snow is old snow from the ending budget year. Photograph taken 30 September 1959 by H. Hoinkes

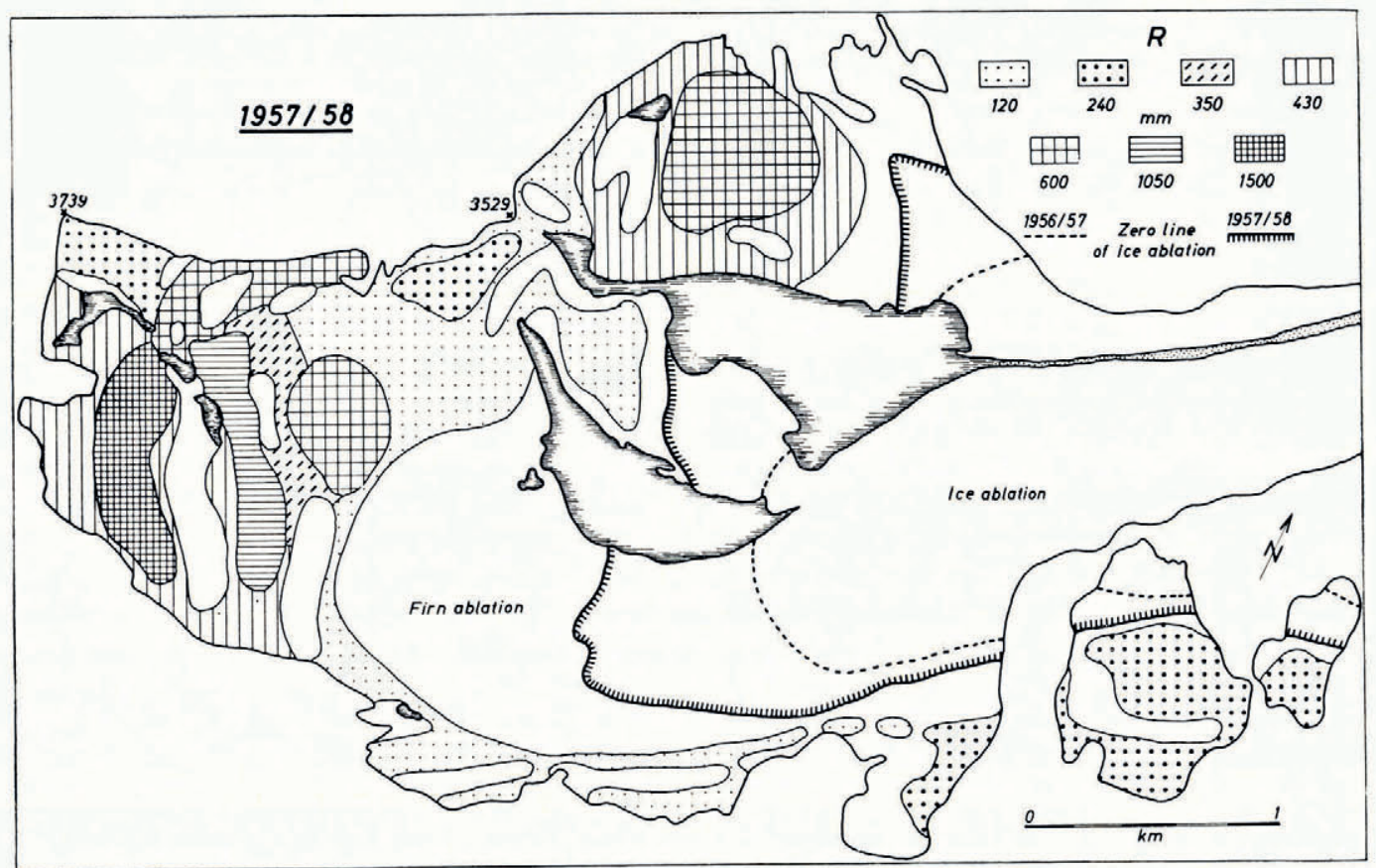

Fig. 8. Net accumulation of old snow on the Hintereisferner at the end of budget year 1957-58. Shadings indicate seven grades of net accumulation in millimetres of water 
(1952); it is caused by differences in accumulation due to the action of the wind, and by different conditions for ablation due to slope, exposure, and possible duration of sunshine. Even avalanches might be responsible for certain patterns. The very existence of enduring accumulation patterns offered a means of improving the estimate of the true total net accumulation. All available photographs, sketches, and notes from different years were used for mapping the accumulation patterns. We had to make do with photographs taken from the surrounding mountains, but without doubt regular aerial photographs, taken as late as possible in the ablation season, would be the best basis for estimates of the total net accumulation, if combined with pit studies.

Figure 8, as an example, shows the mapping of net accumulation patterns on the Hintereisferner at the end of the budget year $1957-58$. Seven grades were used, the different signatures indicating areas with the respective average net accumulation of old snow. Areas without a signature above the zero-line of ice ablation denote areas with firn ablation. Isolated patches without accumulation above the old snow line are found on crevassed ridges or bumps of the terrain (cf. Figure 6);* they are actually much more complicated than shown on the map. The size of these patches was drawn in such a way that ablation of firn and accumulation of old snow compensate each other. All the individual areas were measured with a planimeter, multiplied by their respective average water equivalents of the accumulated old snow, and

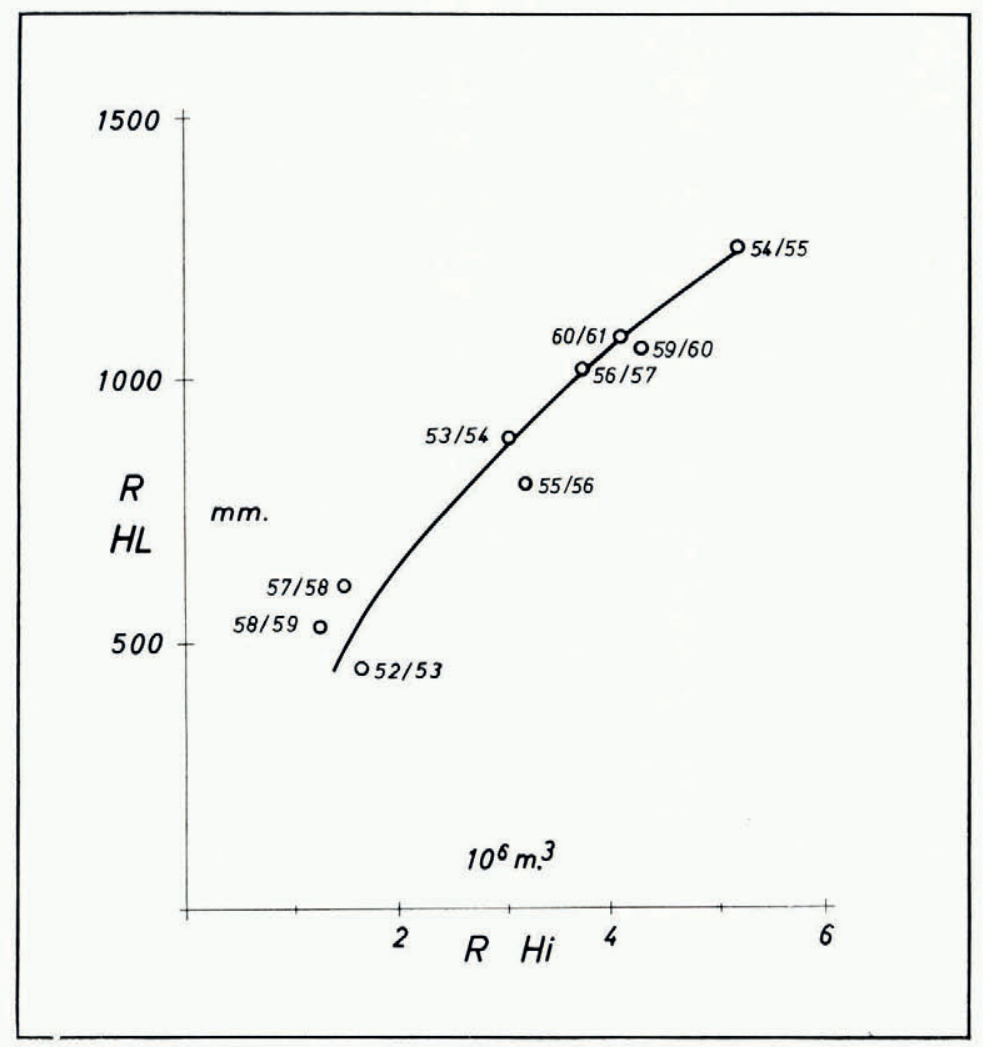

Fig. 9. Relation between net accumulation (millimetres of water) at point $H L(3, I 70 \mathrm{~m}$.) on the Hintereisferner, and total net accumulation on the Hintereisferner (millions of cubic metres of water). Budget years $1952-53$ to $1960-61$

* When comparing Figures 6 and 8, it should be borne in mind that the photograph was taken on 6 September I 958 , i.e. before the end of the ablation season. The site from which the photograph was taken is near the left end of the kilometre scale in the lower right of Figure 8. 
added up in order to give the total net accumulation for the budget year in question. In the budget year $1957^{-58}$ the area with net accumulation of old snow was only $3 \cdot 49 \mathrm{~km} .^{2}$, the total amount $\mathrm{I} \cdot 49 \times 10^{6} \mathrm{~m} .{ }^{3}$ of water. Within the nine years October $195^{2}$ to September ${ }^{96} \mathrm{r}$ the average area with net accumulation of old snow was $5.99 \mathrm{~km} .{ }^{2}$, the average total amount accumulated $3 \cdot$ I I $\times 10^{6} \mathrm{~m} \cdot{ }^{3}$ of water per year (see Table I).

As an important consequence of enduring accumulation patterns which repeat themselves, a connection was to be expected between the net accumulation of a single representative spot within the area of nourishment, and the total net accumulation of the glacier for a certain budget year. This non-linear relation is shown in Figure 9 for the deep pit HL $(3,170 \mathrm{~m}$.) on the Hintereisferner. A similar relation holds between the annual net accumulation as found in the deep pit L 58 (3,240 m.) on the Kesselwandferner and the corresponding total net accumulation of the Hintereisferner. This result, which is now confirmed by the observations of nine years, enables a quick control of the total net accumulation of the Hintereisferner to be made. A corresponding relation exists between the net ablation on the tongue of the Hintereisferner in the height zone 2,700 to 2,800 m., and the total net ablation of the Hintereisferner (Fig. I).

\section{Net Ablation of Firn}

The difference between the total area of the Hintereisferner, and the sum of the areas with net accumulation of old snow and net ablation of ice gives the area with net ablation of firn. This area is usually quite small, except in years with a pronouncedly retreating old snow line, as for example $1957^{-58}$ (see Table I and Figures 6 and 7), when firn layers from several years become exposed to ablation over a comparatively large area. In such years the zero-line of ice ablation is retreating as well, causing firn ablation also below the final position of the zero-line of ice ablation, i.e. in the area between the zero-line of ice ablation of the preceding and the current budget year. This area is included in the area with ice ablation; it might sometimes, as for example in the budget year $1957^{-58}$, reach considerable size. The density of the exposed firn layers was found to vary most frequently between 0.60 and $0.66 \mathrm{~g} . / \mathrm{cm} .^{3}$; the mean value $0.63 \mathrm{~g} . / \mathrm{cm} .{ }^{3}$ was used for calculations of firn ablation. In years with an advancing old snow line, virtually no firn ablation occurs, as for example in I953 to r 955 and in r $959-60$. During the period $195^{2}$ to 196 I the average area of firn ablation between the zero-line of ice ablation and the old snow line was $0.72 \mathrm{~km} .{ }^{2}$, the average total amount of firn lost there had a water equivalent of $-0.17 \times 10^{6} \mathrm{~m} .{ }^{3}$ per year. The average total amount of firn lost below the zero-line of ice ablation is equal to $-0.09 \times 10^{6} \mathrm{~m} .{ }^{3}$ of water per year.

\section{The Mass Balance}

By subtracting the mass loss due to net ablation of ice and firn from the mass gain due to net accumulation of old snow one gets the mass balance of the whole glacier, which is shown graphically in millimetres of water for the whole surface of the glacier in Figure io. In Table I, for the sake of clarity, the mass balance is calculated separately for the area of the glacier covered with old snow or firn (above the zero-line of ice ablation), and for the area showing bare ice at the end of the budget year (below the zero-line of ice ablation). Apart from practical reasons, this sub-division is justified by the appreciable differences in albedo as well as in the roughness parameter between the two kinds of surface. The mass balance for the whole glacier is given in convenient form with respect to the old snow line. There is a large variation in the mass balance of more than ten millions of cubic metres of water between the most favourable budget year 1954-55 with a slightly positive mass balance, and the most unfavourable year I957-58, which will be interpreted in terms of climatic conditions in another report (Hoinkes and Rudolph, ig62).

On an average, more than twice as much mass was used up by net ablation of ice and firn $\left(6 \cdot 7 \mathrm{I} \times \mathrm{IO}^{6} \mathrm{~m} .{ }^{3}\right.$ of water or $667 \mathrm{~mm}$. over $\left.10 \cdot 06 \mathrm{~km} .{ }^{2}\right)$ than was deposited on the glacier by net accumulation of old snow $\left(3 \cdot\right.$ I I $\times 10^{6} \mathrm{~m} .{ }^{3}$ of water or $309 \mathrm{~mm}$. over $\left.10 \cdot 06 \mathrm{~km} .{ }^{2}\right)$. The average 
annual mass loss of the Hintereisferner in the period $195^{2-61}$ amounts to $3 \cdot 60 \times 10^{6} \mathrm{~m} .{ }^{3}$ of water, or $35^{8} \mathrm{~mm}$. of water over an average surface of $10.06 \mathrm{~km} .^{2}$. The average area of nourishment $\left(5.99 \mathrm{~km} .{ }^{2}\right)$ exceeded the average area of wastage $\left(4.07 \mathrm{~km} .{ }^{2}\right)$ by 47 per cent.

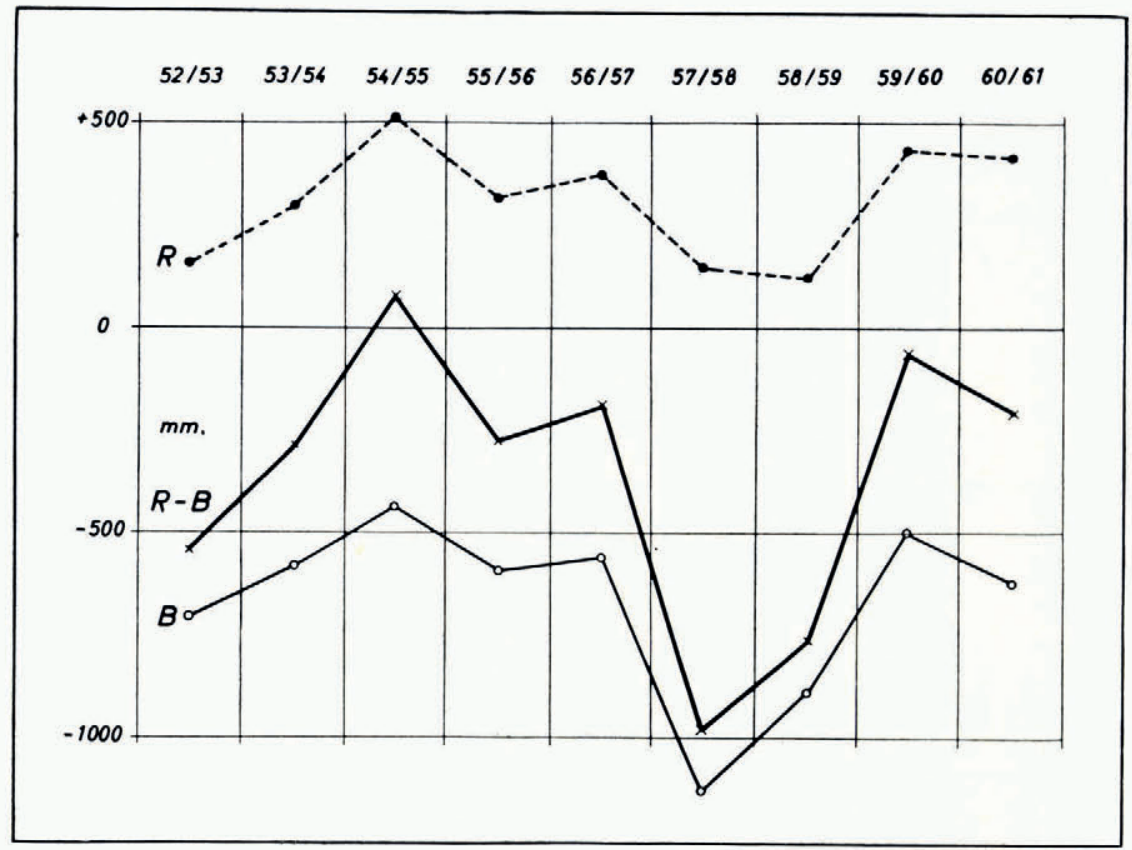

Fig. IO. Total net accumulation $(R)$, total net ablation $(B)$, and mass balance $(R-B)$ in millimetres of water for the whole surface of the Hintereisferner, budget years $1952-53$ to $1960-61$

The average for the nine years is strongly influenced by the two unfavourable years i $957-59$, when net ablation used up more than seven times as much mass ( $10.05 \times 10^{6} \mathrm{~m} . .^{3}$ of water) than was deposited by net accumulation $\left(\mathrm{I} \cdot 38 \times 10^{6} \mathrm{~m} .{ }^{3}\right.$ of water) on an area of nourishment $\left(3.45 \mathrm{~km} .{ }^{2}\right)$ which was only about half that of wastage $\left(6 \cdot 54 \mathrm{~km}^{2}\right)$. More than half (54 per cent) of the $32 \cdot 45 \times 10^{6} \mathrm{~m} .{ }^{3}$ of water lost in the nine years of observation were lost in the two most unfavourable budget years $1957-5^{8}$ and $195^{8-59}$. By adding the budget year $195^{2-53}$ one gets a mass loss of almost three-quarters (7I per cent) of the total, viz. $7.66 \times 10^{6} \mathrm{~m} \cdot{ }^{3}$ of water, or $760 \mathrm{~mm}$. of water over an average surface of $10.08 \mathrm{~km} .^{2}$ per year. For the six remaining budget years $1953-57$ and $1959-6$ I average net ablation of ice and firn $(5 \cdot 5 \mathrm{I} \times$ $10^{6} \mathrm{~m} .{ }^{3}$ of water) was just $4^{0}$ per cent in excess of average net accumulation of old snow $\left(3.93 \times \mathrm{IO}^{6} \mathrm{~m} .{ }^{3}\right.$ of water $)$. The average annual mass loss was only $\mathrm{I} \cdot 58 \times 1 \mathrm{I}^{6} \mathrm{~m} .{ }^{3}$ of water, or $157 \mathrm{~mm}$. of water over an average surface of $10.05 \mathrm{~km} .{ }^{2}$. The average area of nourishment $\left(6.92 \mathrm{~km} .{ }^{2}\right)$ was more than twice as large as the average area of wastage $\left(3 \cdot 13 \mathrm{~km} .{ }^{2}\right)$. In the best budget year so far, I 954-55, with slightly positive mass balance, the area of nourishment was nearly three times as large as the area of wastage (see Table I and Fig. 2).

A lowering of the mean position of the old snow line by about $120 \mathrm{~m}$., down to a height of about 2,830 m., as in the budget year $1954^{-55}$, would be sufficient to bring the Hintereisferner back to equilibrium with respect to the mass balance. The old snow line was in its highest average position in the unfavourable budget years $1957-5^{8}$ and $195^{8-59}$, when it receded to 3, I $20 \mathrm{~m}$. During the six budget years $1953-57$ and $1959-6 \mathrm{I}$ the average position of the old snow line was $2,885 \mathrm{~m}$; for the whole period $195^{2-6} \mathrm{I}$ it was situated at an average height of $2,950 \mathrm{~m}$. 


\section{Estimation of ERrors}

A few remarks seem necessary with regard to the accuracy with which the mass balance components could be determined. Errors in field work on glaciers are hardly to be avoided, because bad weather conditions now and then prevent the collection of complete observations. Such gaps in the material have to be closed rather subjectively by interpolation or reduction. The calculation of total values from erroneous or not representative values may cause errors, the amount of which is not easy to estimate. For a few years we calculated the components of the mass balance with the largest and smallest possible values in order to get an idea of the possible deviations. This was done to the best advantage in the years with measured or recorded run-off from the glacier, i.e. I953-54 (Rudolph, I96I) and I957-59 (Hoinkes and Lang, in press [b]). From these years we reached the conclusion that we were able to determine total net accumulation of old snow to about \pm io per cent, total net ablation of firn to about $\pm \mathrm{r} 5$ per cent, and total net ablation of ice to about \pm 3 per cent. In the worst possible case, when the errors of the single components add up with the same sign, the final average error of the mass balance could amount to about $\pm 0.54 \times 10^{6} \mathrm{~m} .{ }^{3}$ of water (see Table I). The actual error most probably will be smaller, because some compensation is to be expected.

\section{Acknowledgements}

Field work since 1955 and evaluation was sponsored mainly by the Österreichische Akademie der Wissenschaften and by the Hydrographisches Zentralbüro, both in Vienna. Final evaluations for the present report were supported by a grant from the Deutsche Forschungsgemeinschaft to one of us (R.R.). Special thanks are due to the numerous collaborators, mostly undergraduates and graduates from the University of Innsbruck, who offered their help on a voluntary basis. Of these chiefly $\mathrm{H}$. Lang should be named, who contributed most to the field work as well as to the final discussions and conclusions.

\section{REFERENCES}

Ambach, W. 1961. Die Bedeutung des aufgefrorenen Eises (superimposed ice) für den Massen- und Energiehaushalt eines Gletschers. Zeitschrift für Gletscherkunde und Glazialgeologie, Bd. 4, Ht. 3, p. I69-89.

Armstrong, T. E., and Roberts, B. B. 1958. Illustrated ice glossary. Part 2. Polar Record, Vol. 9, No. 59, p. $90-96$. Flint, R. F. [1 957.] Glacial and Pleistocene geology. New York, John Wiley and Sons, Inc.

Friedel, H. 1952. Gesetze der Niederschlagsverteilung im Hochgebirge. IVetter und Leben, Jahrg. 4, Ht. 5-7, p. 73-86. Hoinkes, H. C. 1954. Neue Niederschlagszahlen aus den zentralen Ötztaler Alpen. Fahresbericht des SonnblickVereins, 49-50, 1951-52, p. 19-27.

Hoinkes, H. C. I 956 . Die Bedeutung des aufgefrorenen Eises (superimposed ice) für die Entstehung von Kryokonitlöchern. Zeitschrift für Gletscherkunde und Glazialgeologie, Bd. 3, Ht. 3, p. 305-12.

Hoinkes, H. C. 1957. Zur Bestimmung der Jahresgrenzen in mehrjährigen Schneeansammlungen. Archiv für Meteorologie, Geophysik und Bioklimatologie, Ser. B, Bd. 8, Ht. I, p. 56-6o.

Hoinkes, H. C. 1959. Das glazial-meteorologische Forschungsprogramm in den Ötztaler Alpen. Berichte des Deutschen Wetterdienstes, Bd. 8, Nr. 54, p. 8-13.

Hoinkes, H. C., and Lang, H. In press [a]. Winterschneedecke und Gebietsniederschlag 1957/58 und I958/59 im Bereich des Hintereis- und Kesselwandferners (Ötztaler Alpen). Archiv für Meteorologie, Geophysik und Bioklimatologie, Ser. B.

Hoinkes, H. C., and Lang, H. In press [b]. Der Massenhaushalt von Hintereis- und Kesselwandferner (Ötztaler Alpen), 1957/58 und 1958/59. Archiv für Meteorologie, Geophysik und Bioklimatologie, Ser. B.

Hoinkes, H. C., and Rudolph, R. I962. Variations in the mass-balance of Hintereisferner (Ötztal Alps), I952-61, and their relation to variations of climatic elements. Union Géodésique et Géophysique Internationale. Association Internationale d'Hydrologie Scientifique. Colloque d'Obergurgh, 10-9-18-9 1962. p. I6-28.

Rudolph, R. In press. Abfluss-Studien an Gletscherbächen. Dissertation Universität Innsbruck, r96r. Veröffentlichungen des Museum Ferdinandeum in Innsbruck.

Schimpp, O. 1958. Der Eishaushalt am Hintereisferner in den Jahren 1952/53 und 1953/54. Union Géodésique et Géophysique Internationale. Association Internationale d'Hydrologie Scientifique. Assemblée générale de Toronto, 3-14 sept. 1957. Tom. 4, p. 301-14.

Schimpp, O. 1960. Der Haushalt des Hintereisferners (Ötztal). Akkumulation, Ablation und Gletscherbewegung in den Jahren 1952/53, 1953/54. Veröffentlichungen des Museum Ferdinandeum in Innsbruck, Bd. 39, I959, p. 66-1 38.

Sharp, R. P. 1960. Glaciers. Eugene, Oregon, University of Oregon Press. 


\section{DISCUSSION OF PROFESSOR H. HOINKES' PAPER}

DR. G. DE Q. Robin (Chairman): I would like to start the discussion by asking a little more about superimposed ice at points with negative mass balance. What are the processes actually taking place to permit this?

Professor Hoinkes: Whenever the firn edge is retreating, as it was in the case of those two years, then you have a layer of firn remaining, and the new snow forms on top of it. Then, when it melts, the melt water goes down through this older firn and forms superimposed ice below the say $5^{\circ}$ or $60 \mathrm{~cm}$. of firn, at the surface where the ice begins. Then during the ablation season all the firn is removed and the superimposed ice remains. This is superimposed ice which is clearly from the current budget year, and the mass budget is clearly negative at this point. We have quite a few check points for this, and that is why I feel that only when the firn line is moving down glacier does the existence of superimposed ice necessarily imply positive mass balance.

Dr. V. Schyтt: The original definition of superimposed ice was that it was superimposed on ice, we never thought of it as something which could be superimposed between firn layers.

Professor Hoinkes: In this case it was on glacier ice, but it had firn above it, but near the old snow line those ice layers left the surface of the ice and you could follow them in the firn. This is one reason why we feel that our values for net accumulation may be a little too small - some of the melt water may go down to older layers and form layers of ice there, and if you only dig down to the horizon which you have previously marked as the surface, then of course you may lose a certain amount of water. This was one reason why we tried to dig pits through five or six years' accumulation to check whether the amount in any particular year's accumulation remained about constant; apparently it does to \pm 5 per cent.

DR. J. F. NyE: This glacier seems to show on the average a negative budget. Professor Hoinkes seemed to think this was not very important because sometimes it went positive; may I suggest that this small negative deficit might cause a large retreat of the glacier if continued?

Professor Hoinkes: It does! The snout went back roo m. in I 958-59, but this was because some pieces of old ice broke off and remained in front of the tongue, but even without this the retreat is very fast, in a year the snout goes back by $\sim 25 \mathrm{~m}$., and I agree, even this very small negative mass balance causes a large retreat, I only wanted to point out that it was quite near to equilibrium; the summer of 1960 was not the best, but it was not exceptionally bad.

Dr. NyE: I wanted to point out it might be far from equilibrium. I suggest the illuminating way to present these data is not to give the net budget, but to find out how long the glacier would be if this state of affairs persisted; then we could see whether it was serious or not.

Professor Hoinkes: We have figures for this, too. We know the depth of the rock bed and can calculate the length of tongue which could be kept in equilibrium by the present conditions. Schimpp calculated this to be $3 \mathrm{~km}$. shorter than it is today. We calculated the same quantity by just taking the positive mass balance for the area above the firn edge, and seeing to which line in the ablation area we had the same loss of ice. We came out with an even shorter glacier-instead of ending at $2,400 \mathrm{~m}$. it should end at 2,700 m. a.s.l., and it would lose about half its present mass; but our year, as I tried to show, had an exceptionally negative mass balance and is surely not typical, so I would say that the Hintereisferner, which has a length of 9 to $9.5 \mathrm{~km}$., could be kept in equilibrium under present conditions if you cut about $3 \mathrm{~km}$. off it.

Mr. W. O. FIELD: Was there any relation between the rate of recession during these eight years and the change in the budget?

Professor Hoinkes: I feel that the rate of recession depends very much on the particular conditions at the snout. In some seasons the glacier retreats only very little, and then when 
the tongue becomes very thin from one year to the next you can lose roo $\mathrm{m}$. I do not think this is very significant and therefore I did not look for such a relation.

DR. W. H. WARD: I think anyone who has studied this area around the equilibrium line for any length of time during summer on different glaciers realizes that quite a number of different things can go on. One of the difficult things that I have seen happen is the occurrence of slush avalanches of either old snow or firn coming on to the already ablated glacier ice and forming superimposed ice there. I wonder whether some of the deposits Professor Hoinkes has shown us are formed like this; you have to be there the whole time to be sure.

Professor Hoinkes: We did get this on some occasions, but I do not think they affected our results very much. It occurs in late spring when melt water arrives. It is very hard to get through and sometimes it even remains the whole summer. The name of the Gepatschferner comes from this; patschen means to walk through slush, and the Gepatschferner has a steep tongue and then comes a large, flat area where the firn limit is normally situated. Conditions like that are normal there in summer.

Professor G. Manley: We do our best to have a glacier in Scotland, but all we have is a semi-permanent snow-bed. However it is probably not merely coincidental that two of the years in which it totally disappeared were the two years of the I.G.Y. This agrees well with Professor Hoinkes' results. 